\title{
Environmental factors controlling the palagonitization of the Surtsey tephra, Iceland
}

\author{
SVEINN PETER JAKOBSSON
}

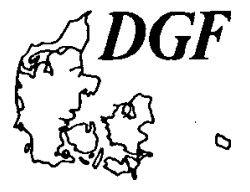

\begin{abstract}
Jakobsson, S. P.: Environmental factors controlling the palagonitization of the Surtsey tephra, Iceland. Bull. geol. Soc. Denmark, vol. 27, Special Issue, pp. 91-105, Copenhagen, July 30th, 1978. https://doi.org/10.37570/bgsd-1978-SI-11

The Surtsey tephra was formed between Nov. 14, 1963 and April 4, 1964 in the phreatic phase of the Surtsey eruption. Since then, the tephra has been inspected annually to follow the expected process of consolidation and palagonitization. In 1969 the first signs of palagonitization of the basaltic glass were observed. The process was clearly connected to the formation of a hydrothermal anomaly established within the tephra pile in 1968. Heat transfer probably occurred by convection of vapourized sea and meteoric water, the heat source being feeder dykes and shallow intrusions. The palagonitization of the Surtsey tephra during $1969-1976$ is inferred to have proceeded at $100^{\circ} \mathrm{C}$ and $1 \mathrm{~atm}$. except in the uppermost 0.5-2 $\mathrm{m}$ where the process has operated down to at least $40^{\circ} \mathrm{C}$. The rate of palagonitization-consolidation is evaluated as a function of temperature and time. Probably most of the tephra pile within the hydrothermal anomaly was palagonitized in less than $1-1 \frac{1}{2}$ years; in 1976 possibly some $64 \%$ of the total tephra pile had become palagonitized. The conditions for the process of palagonitization in general are briefly discussed.
\end{abstract}

Sveinn Peter Jakobsson, Geologisk Museum, Ostervoldgade 5-7, DK-1350 Copenhagen K, Denmark. (On leave from the Icelandic Museum of Natural History, P.O. Box 5320, Reykjavik, Iceland). April 25th, 1978.

The Vestmannaeyjar archipelago (Westman Islands), which is a part of the Eastern Volcanic Zone of Iceland, was recently increased by a new permanent member, the island of Surtsey, formed in the eruptions 1963-1967 (Fig. 1). The first phase of the eruption was phreatic because of the quenching effect of the sea-water and from Nov. 14, 1963 to April 4, 1964 only basaltic tephra was formed. The tephra consisted of unpalagonitized glass, with phenocrysts and rock fragments. The present author has visited the island almost every year since its formation in order to follow the progress of palagonitization and consolidation of the tephra. Samples have been collected at the same localities at regular intervals.

In 1968, a thermal anomaly was discovered in the tephra pile (Friedman \& Williams 1970) and in 1969 the first signs of consolidation and palagonitization in the thermal area were discovered (Jakobsson 1971, 1972). In 1976 most of the tephra within the thermal area was palagonitized. Palagonite is used here for the vitreous, transparent, but usually yellow to brown alteration product of sideromelane (basaltic glass), following Sartorius von Waltershausen (1845, p. 402-403) and Peacock (1926, p. 67-68).
The aim of this report is to elucidate the conditions at which the palagonitization is prodeeding in Surtsey and describe the progressive enlargement of the palagonitized area until 1976. The detailed petrography, mineralogy and chemistry of the Surtsey palagonite and precipitation minerals will be the subject of a later publication.

\section{The eruption history and structure of Surtsey}

The eruption history of Surtsey and the two adjacent islands which temporarily formed during 1963-1967 has been described in detail by Thorarinsson et al. (1964) and Thorarinsson (1966, 1968), so only a short summary will be given here. The visible eruption started with phreatic explosions on November 14, 1963 at a site where the water depth was about $128 \mathrm{~m}$ and this phreatic phase lasted until April 4, 1964. Two tephra rings, with a diameter of about $420 \mathrm{~m}$ and $500 \mathrm{~m}$, respectively, were formed (Fig. 1). Their maximum height was $173 \mathrm{~m}$ a.s.l. and about $301 \mathrm{~m}$ above the seabottom (cf. Fig. 3). After April 4, 


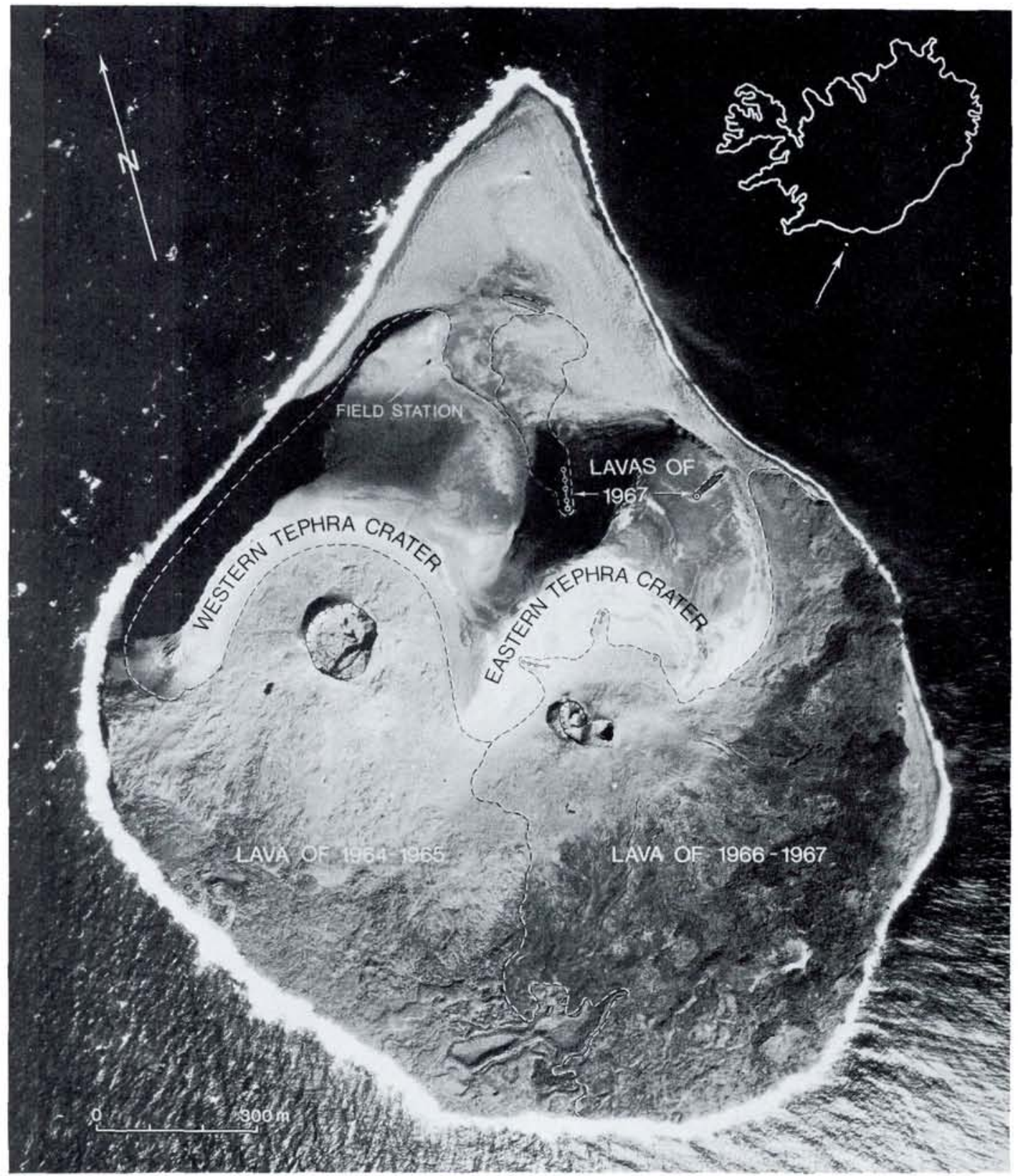

Fig. 1. Air photograph of Surtsey, taken on Sept. 25, 1976, by the Icelandic Geodetic Survey. The area of primary tephra, lava craters and the 1964-65 and 1966-67 lavas are indicated. The

1964 , the eruption changed over to an effusie pha$\mathrm{se}$, as the island was then obviously large enough to isolate the feeder channel from the inflow of seawater. During the last week of December 1963, there was simultaneously a phreatic eruption on the sea bottom about $200 \mathrm{~m}$ NE of Surtsey, no island inset map shows the regional location; the position of Surtsey is N $63^{\circ} 18^{\prime} 22^{\prime \prime}$ and $W 20^{\circ} 36^{\prime} 56^{\prime \prime}$.

was formed, however. On Surtsey the lava flowed from the crater (the western crater of Fig. 1) until May 17, 1965 and gradually built up a flat lava plain towards the south, with foreset breccia (Saemundsson 1967) forming at the same time below sea level (Fig. 3). Then, after a few days interval a 
new vent began eruptions on May 22, 1965, at a site about $600 \mathrm{~m}$ ENE of Surtsey. A small island, called Syrtlingur (little Surtsey) formed, entirely built up of tephra. This island was destroyed by wave action a few days after the eruptions ceased on October 17, 1965. Another island, Jolnir (Christmas Island), arose from the seabottom some $800 \mathrm{~m}$ SW on December 25, 1965. Phreatic eruptions continued at this site until August 10, 1966, shortly after which this island also disappeared. On Surtsey new eruptions started on August 19, 1966 and lava was erupted from altogether six sites in the eastern tephra crater. The new lava flowed mainly to the east and south (Fig. 1) and added considerably to the size of the island. Lava was last seen to flow on June 5, 1967; the size of Surtsey was then $2.8 \mathrm{~km}^{2}$, and the total amount of material erupted was estimated to be $1.2 \mathrm{~km}^{3}$.

The tephra was deposited by air fall, and also base-surge flows (Lorenz, 1974). Two types of explosive activity dominated, intermittent "cockstail" explosions and continous uprush of tephra (Thorarinsson 1966). The tephra is very poorly sorted, with some $19 \%$ in the "fine ash" fraction ( $<0.06 \mathrm{~mm}), 67 \%$ as "coarse ash" $(0.06-2 \mathrm{~mm})$ and some $14 \%$ as "lapilli" (2-64 mm), - less than $1 / 2 \%$ falling into the fraction of "blocks and bombs" (> $64 \mathrm{~mm}$ ) following the classification of Fisher (1961). For further reading on the mode of emplacement and physical properties of the tephra the reader is referred to Walker \& Crosdale(1972), Lorenz (1974) and Jakobsson (1971). The material erupted from the various eruption sites was alkali olivini-basalt with slight compositional changes, possibly mainly due to variations in content of olivine phenocrysts.

It has been shown by Kjartansson (1966) and Thorarinsson (1966) that structurally Surtsey bears a close resemblance to the Icelandic tuyas (stapi in Icel.). However, the important structural unit of the tuyas, the pillow lava, has not been proven to exist in Surtsey, although Kjartansson and Thorarinsson have assumed, mainly by analogy with the tuyas, that it forms the base of Surtsey. McBirney (1963) has shown, that explosive basaltic eruptions will be able to occur down to water depths of around 500 metres. According to Jones (1970) pillow lavas are usually not found in the uppermost couple of hundred metres of inferred water depth in the intraglacial tuyas of the Laugarvatn region, although pillow lava in one case occurs at around $100 \mathrm{~m}$ depth. The water depth at the site of Surtsey was only about $128 \mathrm{~m}$ before eruption. Finally, geomagnetic measurements on Surtsey (Sigurgeirsson 1966, 1974) apparantly do not indicate the presence of any pillow lava between the seabottom level and the tephra pile.

\section{The thermal anomaly}

Until early 1968 ambient temperature conditions apparently prevailed in the tephra pile of Surtsey. The mean monthly air temperature for Vestmannaeyjar vary between $0^{\circ}-10^{\circ} \mathrm{C}$, although diurnal and seasonal variations can give twice this value. Thus temperature measurements carried out during April-August 1968 (Sigtryggsson 1970) on the northern coast of Surtsey, showed that temperatures varied between $5-17^{\circ} \mathrm{C}$ at $5 \mathrm{~cm}$ depth in tephra. The average annual precipitation for the nearby Storhöfdi weather station is around $1450 \mathrm{~mm}$. Temperature and humidity are probably the two important parametres to control the rate of palagonitization of basaltic glasses (Hay \& Ijima 1968, Honnorez 1972 and Furnes 1975). Under the above mentioned conditions no palagonitization would take place in Surtsey in the observed period and no trace of palagonite was in fact found in tephra samples collected from 1964 to 1967.

No anomalous temperatures were observed in the field as late as July 1967 but in April 1968 an anomaly was discovered by geologists on the top of the eastern tephra crater and a clear thermal anomaly was visible in the inner wall of the eastern tephra crater on infrared images from August 1968 (Friedman \& Williams 1971). The extent of the thermal area at the surface within the tephra area was mapped provisionally in November 1969 (Fig. 5) and in detail in August 1970 (Fig. 6) (Jakobsson 1972), and nearly every year since then (e.g. Figs. 7 and 8). Temperature measurements were made with an Atkins thermistor thermometer at a depth of $20 \mathrm{~cm}$ in order to avoid effects of diurnal fluctuations and minimize effects of seasonal variations. The boundary of the thermal area was consequently defined by the $20^{\circ} \mathrm{C}$ isotherm.

When the infrared airphoto of August 1968 is studied, it is evident that heat has mainly found its way along the angular unconformity in the inner 
wall of the eastern crater and the feeders to the craters.

In the first year of the thermal anomaly the whole area was drenched wet and in several places steam was seen to escape from small fissures in tephra. Between 1969-1972 surface temperatures of $40-50^{\circ} \mathrm{C}$ were common in the center of the thermal area, but in fissures where emanation of steam was strong, specially in and around lava craters, temperatures up to $100^{\circ} \mathrm{C}$ were obtained, which characteristically is the highest temperature measured in the tephra. After the tephra started to consolidate it became difficult to carry out temperature measurements. A vertical thermal gradient of around $120-140^{\circ} \mathrm{C} / \mathrm{m}$ was not uncommon in the first three years, falling to about $50^{\circ} \mathrm{C} / \mathrm{m}$ at the borders of the thermal area which were usually sharp.

During a 38-day period in November and December 1972, semidiurnal temperature data were transmitted via the Landsat-1 Data Collection System from a site in the topographic saddle between the two tephra rings. (Friedman et al. 1976). Air temperatures, surface temperatures and I-mdepth temperatures were obtained simultaneously. A near surface vertical gradient of $69.4^{\circ} \mathrm{C} / \mathrm{m}$ was observed and at the site of the Data Collection System a net geothermal flux of $780 \pm 325 \mu$-cal $\mathrm{cm}^{-2} \mathrm{~s}^{-1}$ was obtained. An interesting feature of the measurements are temperature fluctuations of the order of $10-18^{\circ} \mathrm{C}$ at $1-\mathrm{m}$ depth. Similar and larger fluctuations (up to $30-40^{\circ} \mathrm{C}$ within a few days and $2-4^{\circ} \mathrm{C}$ within minutes), sometimes accompanied by similar fluctuations in steam output, were observed in 1971 and 1972 by the author and the summer guard on Surtsey. Such spasmodic pulses in temperature and output of steam requires convective venting as an explanation. The $1-\mathrm{m}$ depth curves of the Landsat DCS experiment and daily surface measurements in periods in August-September 1970 and July-August 1971 have now been compared to the variations in barometric pressure for the same periods at Storhöfdi, a weather station on Heimaey about $19 \mathrm{~km}$ to the NE. There appears to be a distinct correlation between the variations in the temperature and the barometric pressure. All the peaks on the two l-m depth curves of November-December 1972 (Friedman et al. 1976, Fig. 3) correspond to lows in the barometric curve of Storhofdi. It is therefore probable that the main reason for the observed temperature fluc- tuations is pulling effect caused by variations in the barometric pressure. Precipitation might also be expected to have influenced the temperature fluctuations but no correlation has been found.

It was concluded by Friedman et al. (1976) that the mechanism of heat transfer in the thermal area in Surtsey was partitioned between conduction and convection of water vapour. Reevaluation of the available data points. however, to a convective mechanism. The fact that temperatures above $100^{\circ} \mathrm{C}$ were never measured, that the day to day temperature fluctuations were of the order of tens of degress, that a vapour phase was present at all times and the likelihood that substantial part of the vapour phase is of seawater origin (see next section) all indicate that convective heat transfer has been a more important factor than conduction in the production of the thermal tephra anomaly on Surtsey.

\section{Origin of the water vapour}

In an attemt to unveil the origin of the water vapour moving through the tephra pile in Surtsey, samples of condensed water vapour for deuterium analysis were collected at three localities (Fig. 6) within the thermal area. The vapour can be derived from precipitation or seawater, or be a mixture of these two components. As the deuterium content of meteoric and sea water is quite different, an analysis of the condensate might give a clue to the origin of the vapour. The measured $\delta_{D}$ - values, which were determined by Dr. B. Arnason, are listed in Table 1 along with average values for precipitation at the south coast of Iceland (Arnason 1977). "Standard Mean Ocean Water" (SMOW) is used as reference standard for deuterium measurements of natural water. The $\delta_{D}-$ values fall into two sets, the vapour condensates with the high values of $-4.2 \%$ and $-5.2 \%$ are probably of sea water origin, whereas the other samples are probably mainly precipitation by origin (Arnason, pers. comm.) as these values, - 46.2 and $-59.1 \%$ are close to the mean deuterium value of precipitation at the nearby south coast (Arnason \& Sigurgeirsson 1968, Arnason 1977).

It is noteworthy that the two condensate samples, collected where steam emanation was vigourous in 1971, i.e. in the two lava craters (Table 1, I and IV), show deuterium values which are closest 
to sea water, whereas the other two samples, which were collected in tephra with a considerably slower emanation (Table 1, II and III) show values, which are indicative of a meteoric origin. In summary the deuterium measurements indicate that at least part of the vapour is of seawater origin and that it was able to reach surface at the craters without mixing appreciably with the meteoric component. Outside the large craters and their feeder channels the vapour may be vapourized sea water mixed with meteoric water or more probably pure meteoric water which seeps down to a heat source (e. g. shallow intrusions), becomes vapourized and moves upwards to escape through surface. If we assume that the heat transfer is mainly by convection, the high porosity of the tephra (the porosity can be estimated to be about $15-25 \%$ ) will probably not cause any substantial pressure to be built up. It can therefore be suggested that temperatures around $100^{\circ} \mathrm{C}$ prevail above sea level in the tephra pile and that palagonitization therefore proceeds generally at $100^{\circ} \mathrm{C}$ and $1 \mathrm{~atm}$. If, however, the heat transfer is partitioned between conduction and convection, considerably higher temperatures may exist locally.

The $\mathrm{pH}$ of the vapour condensates varies between 7.7 and 8.3 (Table 1), which is about the same range as found in sea water. These values have, however, to be interpreted with caution as the tephra contains appreciable amounts of sea salts at the time of their deposition (Sigvaldason \& Fridriksson 1968). The measured $\mathrm{pH}$ values can therefore probably not exclude a meteoric origin.

Table 1. Deuterium concentration and $\mathrm{pH}$ of water vapour condensate collected in Surtsey on October 12, 1971, analyst Bragi Arnason. For location of sample sites, see Fig. 6. Values for seawater (Dietrich et al. 1975) and precipitation at south of Iceland (Arnason 1977 \& Vedrattan (1970) are shown for comparison.

\section{SAMPLE SITE}

I. Steaming hole in the small lava . crater on the west side of eastern tephra crater.

$\delta_{D} \% \quad \mathrm{pH}$

Small fissure in lava about $90 \mathrm{~m}$ below site I.

$\div 4.2$

$\div 46.2 \quad 7.7$

III. Small fissure in hard tuff, south east corner of eastern tephra crater.

$\div 59.1 \quad 8.2$

IV. Icicle formed of steam condensate in the largest eastern lava crater.

$\div 5.2 \quad 6.2$

V. Sea-water.

$0 \quad \sim 8.2$

VI. Precipitation at south coast of Iceland.
Hay \& Ijima (1968b) suggested higher $\mathrm{pH}$ for percolating water in the tephra deposits of the Honolulu Group on Oahu at time of palagonitization, or pH 9 to 9.5. On the floor of Kilauea caldera palagonite is presently forming along steaming cracks at a temperature range of $76-91^{\circ} \mathrm{C}$ and a $\mathrm{pH}$ of approximately 6 (Hay et al. 1969).

\section{The heat source}

As stated previously (Jakobsson 1972) the thermal area was, especially in the beginning, confined to the area around the 1966-67 lava eruption sites, and this, along with the fact that the thermal area came into being about $1 / 2$ to $11 / 2$ year (i.e. between July 1967 and April 1968) after the cessation of eruptive activity in the craters, strongly suggests that the heat source is these lava craters and their feeders. Another possibility is that the heat source is a pillow lava pile which may have formed in the last few days preceeding the visible eruption in Surtsey on November 14, 1963 (Thorarinsson 1966 and Kjartansson 1966). It has been suggested (Sigvaldason 1968) that pillow lava piles which often form the base of subaquatic volcanic structures serve as heat source and thus are the main agent for palagonitization in these structures. However, besides the absence of any proof for the existence of pillow lava in the basal part of Surtsey, the late emergence of the thermal anomaly speaks against a pillow lava as heat source.

Temperature measurements on Surtsey (Jakobsson 1972, Johannesson, in press) show, that the lava retains its heat for a relatively long time. Two small hot areas close to the western lava crater have been kept under observation since 1969 and 1971, respectively. Maximum temperature was recorded each time on or slightly below surface in lava fissures. Temperatures in both areas show a steady fall with time and can be tentatively extrapolated to the measured extrusion temperature of the lava at the time of eruption (Fig. 2). The heat may derive from the cooling lava pile, which is respectively about $100 \mathrm{~m}$ thick (site 1 ) and $40 \mathrm{~m}$ thick (site 2) and/or the feeder dyke along with other eventual small intrusions. No thermal anomaly was formed in the surrounding tephra of the western crater, presumably because no feeders or other intrusions cut the tephra pile. This was, ho- 


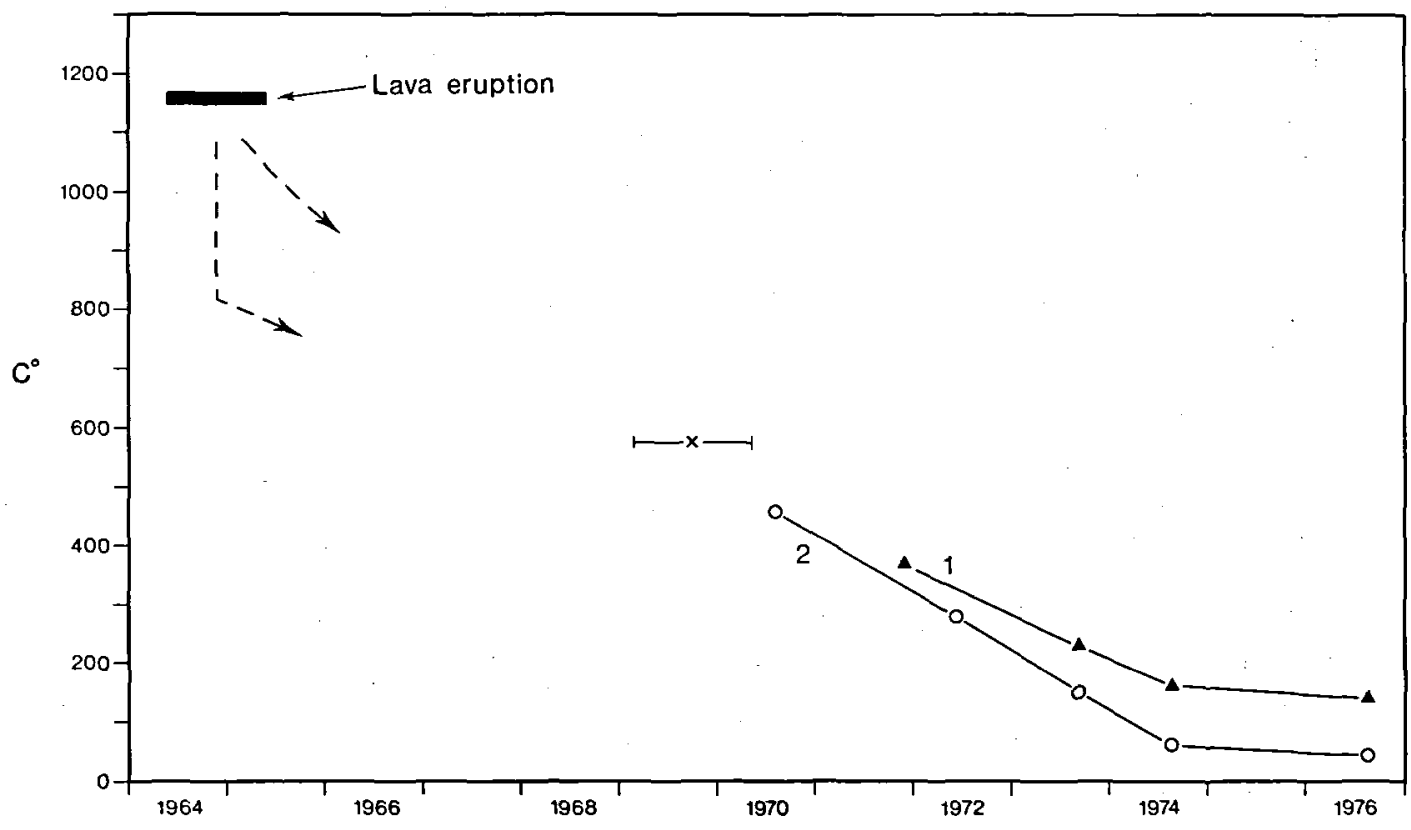

Fig. 2. Temperature measurements at two localities at the western lava crater during 1970-76, cf. Fig. 6. The maximum temperature measured each time near surface is shown along with the extrusion temperature of the magma. The cross with the bar indicates the time when the basalt pile at site I apparently cooled below the Curie point (Sigurgeirsson 1974).

wever, the case in the eastern tephra ring and consequently a thermal anomaly could be observed on the surface shortly after the lava eruptions ceased. There are no comparable temperature readings from the eastern 1966-67 lava field, but it was observed to cool faster than the western lave pile. Nevertheless, by analogy, feeders and other possible intrusions may have been adequate to account for the hydrothermal anomaly. After about 1972 a general decline in the temperature within the thermal area could be observed.

Fig 3 is a profile through the eastern part of Surtsey, from SW to NE. The estimated extent of the thermal anomaly is shown schematically at depth. No pillow lavas are shown for the reasons discussed earlier. In this model it is assumed in light of the above discussion, that the vapour is of sea water origin, mixed to some unknown degree with precipitation at higher level to become nearly pure meteoric water at surface and that the heat source is feeder dykes and possibly other small intrusive bodies at or above sealevel. The thermal anomaly will therefore not extend appreciably below sea level.

Time A.D.

Until 1972 the temperature within the thermal area had been roughly constant, if minor fluctuations are neglected. Nevertheless the thermal area mapped on the surface expanded somewhat between 1969 and 1976 (Figs. 5-8), particularly towards west. Since no new volcanic extrusive or intrusive activity that could have caused the expansion of the thermal anomaly has been recorded on Surtsey during the period, two other explanations may be considered. First, it may be suggested that the transition of tephra to tuff has rendered the rock less permeable for the vapour flow which then escapes to the sides, thereby widening the thermal area (cf. also Johanesson, in press). However, although most of the tephra inside the thermal area is now compact rock, no substantial decrease in porosity has been observed in thin sections. The process of palagonitization appears to be isovoluminous (Hay \& Ijima 1968 and Jakobsson 1972) and the secondary minerals still only amount to some $2-8 \%$ of the whole rock. An alternative explanation for the enlargement of the thermal area is the possibly supply of heat from the transformation of gelpalagonite to the fibro- 


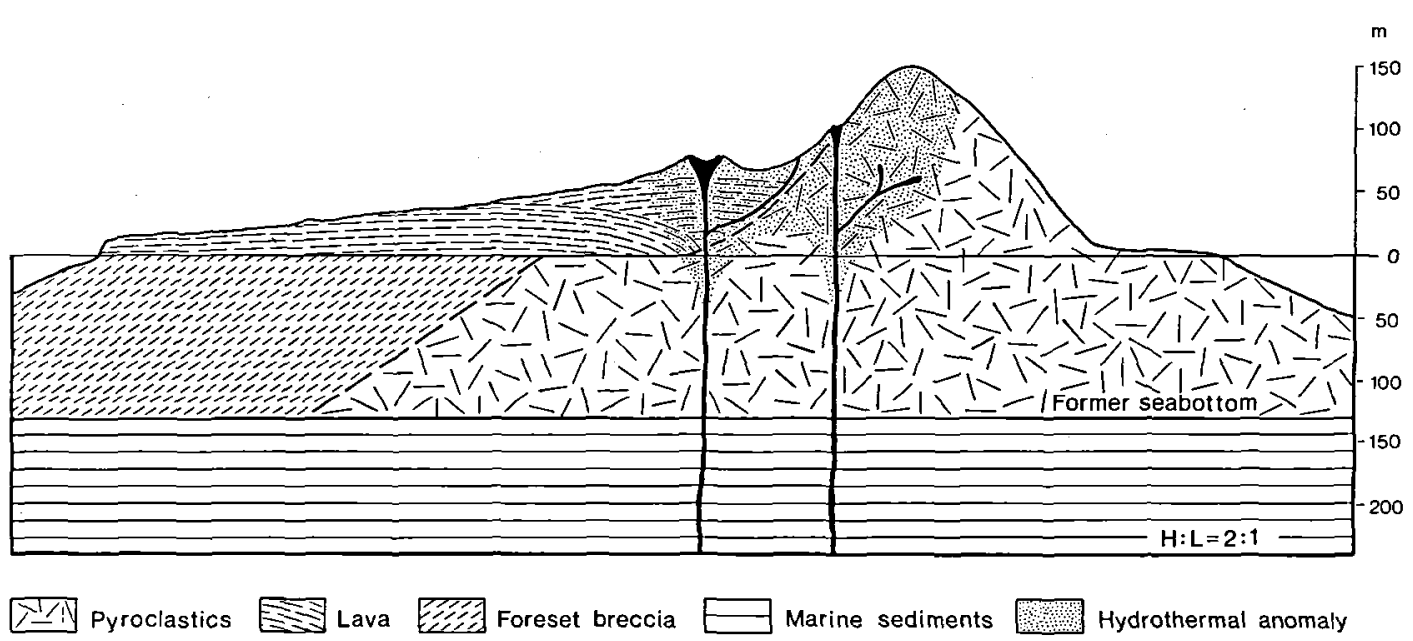

Fig. 3. Profile through the eastern tephra and lava craters from SW to NE. The pyroclastics formed between approx. Nov. 14; 1963 and April 4, 1966. Feeder dykes, craters and lava with foreset breccia formed during Aug. 19, 1966 - May 5, 1967. The estimated extent of the hydrothermal anomaly as in 1970 is indicated by shading.

palagonite. It may be tentatively suggested, although it has not been further investigated, that the heat produced by devitrification of the gelpalagonite has helped to maintain the thermal area in Surtsey and even caused its expansion.

\section{The rate of palagonitization and consolidation in Surtsey}

If the authors interpretations for the source and the origin of the water vapour are correct, this will mean that the process of palagonitization in Surtsey occurs in the presence of abundant water vapour at $100^{\circ} \mathrm{C}$ with a $\mathrm{pH}$ of $7.7-8.2$ and a pressure of $1 \mathrm{~atm}$. These conditions will be prevailing at least in the upper part of the tephra pile, except near the surface where there is a steep thermal gradient in the uppermost $1 / 2-2 \mathrm{~m}$.

It is possible to estimate the rate of palagonitization and consolidation of the Surtsey tephra on the basis of surface observations in the years 1969 -1976 . Although the temperature of the thermal area was generally seen to fall about 3-4 years after the establishment of the thermal area, temperatures could be estimated as being roughly constant at several localities and spots, disregarding the minor fluctuations of up to $10-18^{\circ} \mathrm{C}$ mentioned above. The rate of palagonitization and consolidation is shown in Fig. 4 as function of time and temperature of the water. The diagram is based on observations at 11 separate localities on the surface, and the precision of each point is estimated to be about \pm 6 months on the time scale (for the whole set of observations) and about \pm 5$10^{\circ} \mathrm{C}$ on the temperature scale (for each point).

When the first signs of palagonitization were visually observed in the field - usually as dispersed red brown patches accompanied by the beginning of consolidation of the tephra - an "incipient palagonitization"' (Fig. 4) was noted. In many cases, samples were collected and checked by thin section inspection. Apparently a palagonite layer of about $10-15$ microns is thick enough to give the grains a distinct colour. Therefore, the line in Fig. 4 , which marks the beginning of palagonitization, indicates that at least 10-15 microns of palagonite has formed sporadically in the tephra. Samples collected as showing "incipient palagonitization" characteristically have less than $5 \%$ vol. palagonite. Alternatively, the rock was classified as "dense palagonitized tuff" in the field when it was well consolidated, - thin section inspection showed that usually $10-30 \%$ vol. is palagonite in 


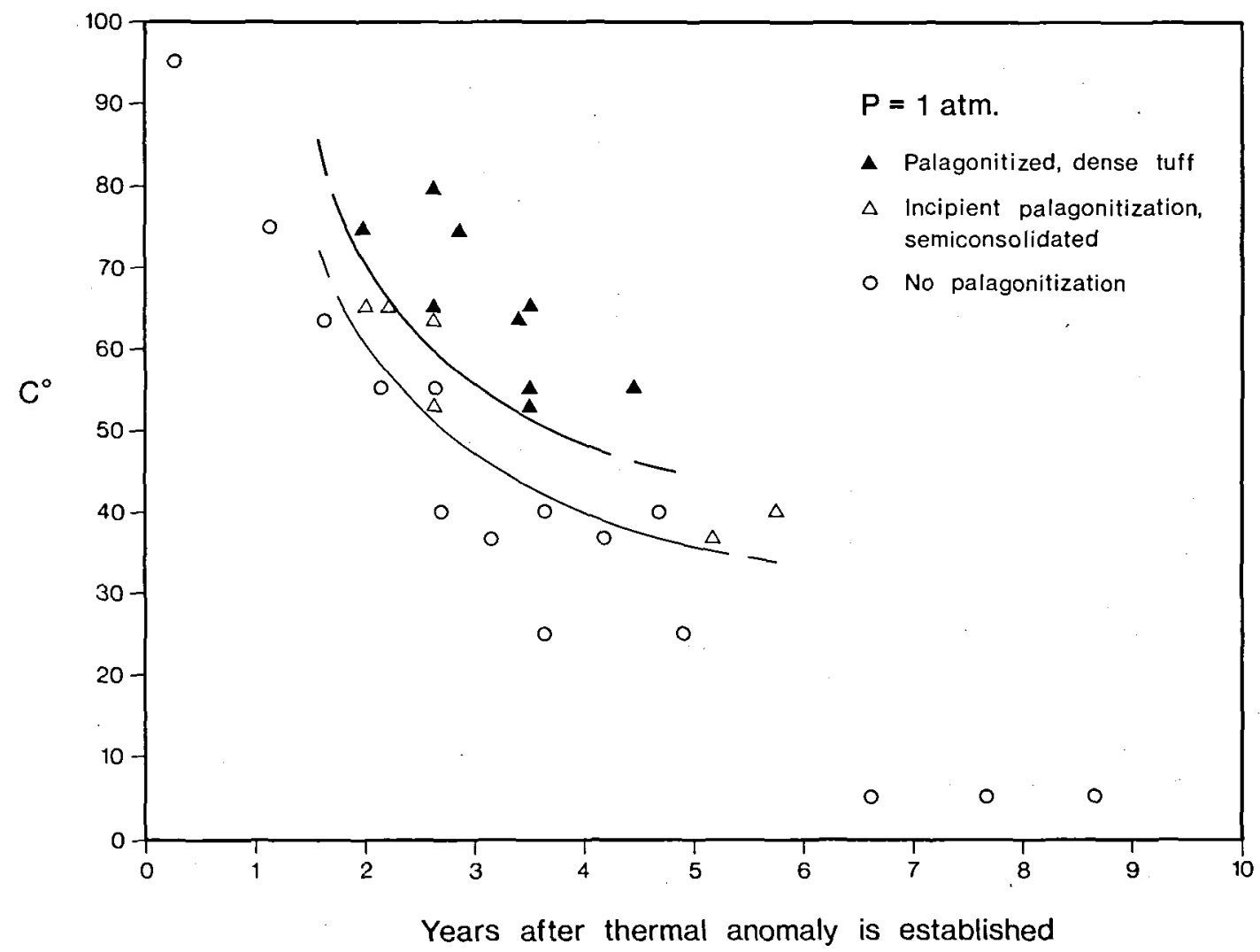

Fig. 4. The rate of palagonitization and consolidation in Surtsey tephra as function of temperature and time. Based on surface observations at 11 localities between 1968-1976.

these samples. It must be noted here, however, that there appears to be a complex relation between palagonitization and consolidation. In the beginning, at least, the palagonite is too dispersed to be responsible for the cementation of the grains. Therefore the tephra consolidation must be caused by something else than the precipitation of alteration products:

Two main conclusions can be drawn from Fig. 4 . First, at approximately $100^{\circ} \mathrm{C}$ (valid for main part of pile) it is probably a matter of less than 1$1 \frac{1}{2}$ year before the tephra is converted into dense palagonitized tuff with some $5-12 \%$ volume palagonite. The palagonitization of the rock will of course continue with time in the field of dense tuff. Second, below about $50^{\circ} \mathrm{C}$ the rate of palagonitization and consolidation falls considerably. Below some $35^{\circ} \mathrm{C}$ no signs of palagonitization has been found in the Surtsey tephra in the first six years, after that period of time the cooling of the ther- mal area was everywhere noticable, so observations on the rate of palagonitization above atmospheric temperatures were not practicable after that time.

Furnes (1975) has investigated the rate of palagonitization of different artificially quenched basaltic glasses, submerged in fresh and saline water at $1 \mathrm{~atm}$. It is of interest to note that he found a marked decrease in the rate of palagonitization between runs at $70^{\circ} \mathrm{C}$ and $43^{\circ} \mathrm{C}$. Although it is obviously difficult to make comparisons between these experiments and what is happening in Surtsey it seems possible that there is a connection between this experimentally observed decrease and the pronounced decrease in rate of palagonitization below about $50^{\circ} \mathrm{C}$ in Surtsey (Fig. 4).

As already shown, probably the main part of the tephra pile within the thermal anomaly was exposed to temperatures around $100^{\circ} \mathrm{C}$. Observations on the rate of cooling of the thermal area in- 
dicate that the main part of this tephra will stay at this temperature for something like 8-20 years and remain som additional 6-10 years within the field of "dense palagonitized tuff" (Fig. 4) before it cools down to ambient temperature. This rock is therefore exposed to moderate temperatures accompanied with rapid palagonitization for a short time before it cools to temperatures of $0-10^{\circ} \mathrm{C}$, where palagonitization proceeds very slowly (Moore 1966, Jakobsson 1972, Furnes 1975). These relations may explain the occasional zoning. of palagonite found in older hyaloclastic rocks.

The question is then when the tephra outside the thermal area will become palagonitized, and what the rate of palagonitization of this tephra will be. Jonsson (1961) has shown, that recent glaciofluviatile sediments in Iceland and postglacial basaltic tepralayers in soil of an age of about 1200 years are palagonitized and this must have happened at weathering conditions $\left(0-10^{\circ} \mathrm{C}\right)$. It is also the opinion of the present author, that a substantial part of the Icelandic "Palagonite Formation" is altered at weathering conditions, as large parts of this formation lack the signs of alteration by mild hydrothermal activity as in Surtsey (see p. 104). It may provisionally be suggested that what is called "incipient palagonitization" in Surtsey is not reached in tephra at weathering temperatures before much longer time has passed, possibly several thousand years (cf. Jóhnsson 1961).

The rather poor definition of the field term "incipient palagonitization" in Fig. 4 is probably mainly due to variations in steam flux through the tephra, structural control and grain size control. Generally it can be said, that the greater the porosity of the tephra is, the higher is the steamflux. Consequently porous tephra layers will be palagonitized and consolidated quicker than more dense layers. And finer grained layers appear to be more quickly cemented than the coarse ones.

In connection with the present evaluation of the Surtsey data it is of special interest to note that Heiken (1972) had deduced that palagonitization of the tuff rings of South Central Oregon had occurred under condition very similar to those observed in Surtsey. He had suggested that intensely altered palagonite tuffs in some of the tuff rings were altered due to reaction with steam, whereas alteration in tuff beds outside the crater area was primarily due to weathering.

Although it is possible to outline the overall rate of the palagonitization-consolidation of the Surtsey tephra as shown in Fig. 4, it appears difficult to state the rate of palagonitization in terms of thickness of palagonite rind on glass shards as function of time, as Moore (1966) was able to demonstrate for submarine basaltic glass at Hawaii. As the palagonitization agent in Surtsey is steam, the thickness of palagonite rind can vary considerably, even in the same handspecimen, as the steam has not everywhere the same access to the glass shards because of varying porosity). Within an area of about $1 \mathrm{~m}^{2}$, the thickness of palagonite was found to vary as much as $0-1500 \mu$ ! Where the steam flux has been particularly strong the sides of the shards facing the steam flow are extensively palagonitized, whereas the opposite sides may be unpalagonitized. The difference between the Surtsey case and that of the submarine pillows of $\mathrm{Ha}$ waii is principially that of enviroment; under submarine conditions the process of palagonitization will proceed evenly, whereas in Surtsey the process may proceed both unevenly on the centimeter scale and periodically. Consequently, hyaloclastites palagonitized subaerially will generally not be suitable for dating by measurement of the thickness of palagonite rind.

Palagonitization of the Surtsey tephra was first observed in September 1969 (Jakobsson, 1972) in the SE corner of the eastern tephra ring (Fig. 2). Some 1-2\% vol. of the rock was palagonitized; this palagonite is of the type called gelpalagonite by Peacock (1926, p. 67-68). Gelpalagonite is an isotropic, usually yellow, type of palagonite and no crystalline phases (apart from those already present as phenocrysts and microlites) are discernible by optical microscopy or $\mathrm{x}$-ray diffractometer analysis. Preliminary microprobe analyses on a sample taken at this locality in November 1969 , indicated that during the palagonitization the following components were lost in order of relative amounts: $\mathrm{Na}_{2} \mathrm{O}, \mathrm{K}_{2} \mathrm{O}, \mathrm{CaO}, \mathrm{Al}_{2} \mathrm{O}_{3}, \mathrm{SiO}_{2} . \mathrm{MgO}, \mathrm{TiO}_{2}$ and $\mathrm{Fe} 0$ (oxidized to $\mathrm{Fe}_{2} \mathrm{O}_{3}$ during the process) were possibly being constant on volume basis. Instead $\mathrm{H}_{2} \mathrm{O}$ enters the palagonite, possibly up to 30 $35 \%$ by weight.

Fibropalagonite was discovered for the first time in Surtsey in samples collected in September 1976 at the same locality as mentioned above, it appears to replace gelpalagonite, according to thin section studies. Fibropalagonite is a brownish, birefringent, fibrous type of palagonite (Peacock 


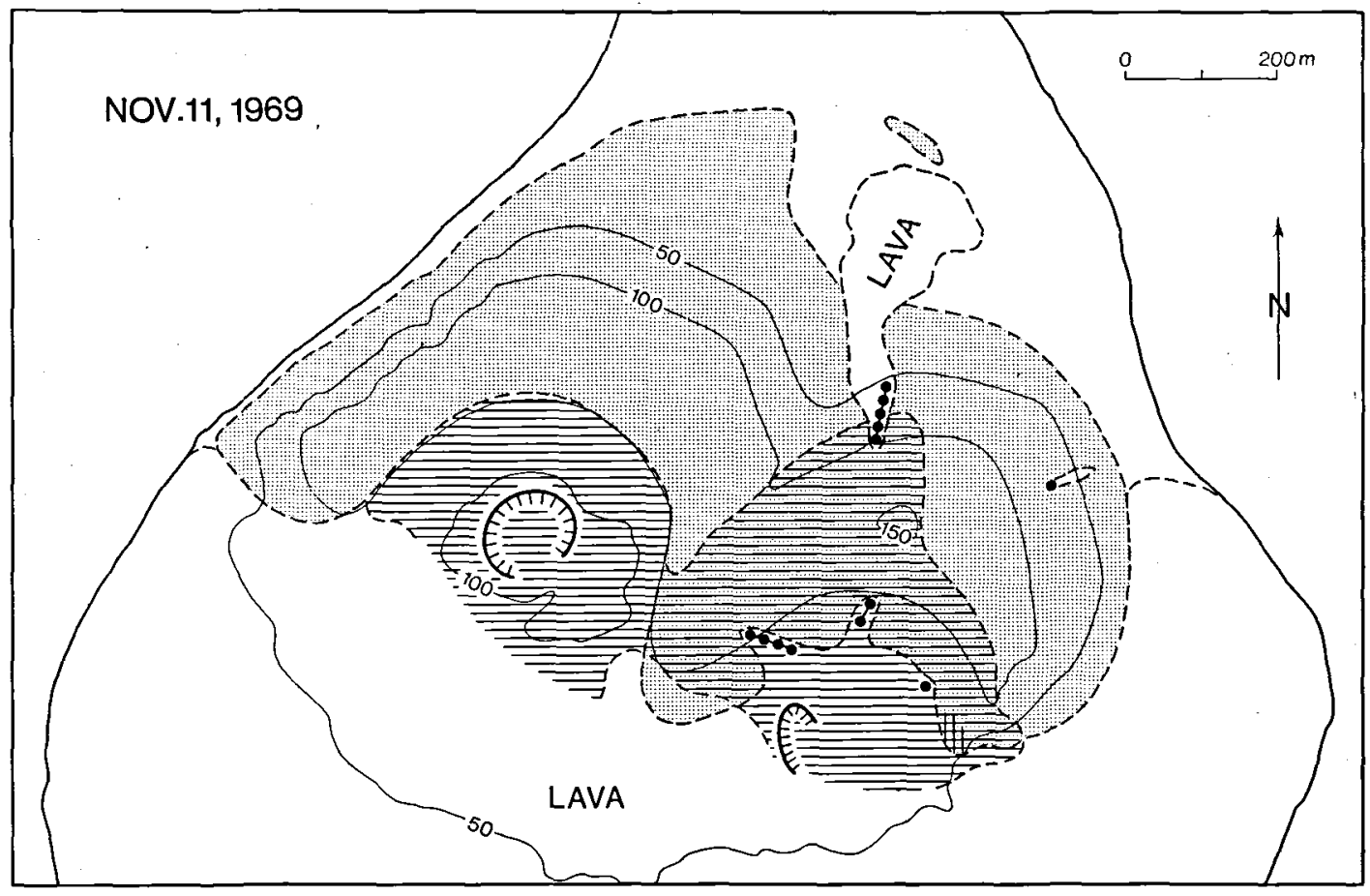

Fig. 5. Map of the northern part of Surtsey. The area of primary tephra is shown by stippled. The approximate extent of the hydrothermal area (horizontal lines) and surface exposures of the palagonitized area (cross hatching) as in September 1969 are in- dicated. Outline of island and height contours after Norrman 1970 (based on air photographs of July 6, 1968). Compare Fig. 1 .
1926). These fibres have been found to consist of variety of minerals, smectites being the most common (Nayudu 1964, Hay \& Ijima 1968 and Honnorez 1972). It is therefore established in this case, that gelpalagonite is formed first during the palagonitization of sideromelane, a few years later to be followed by fibropalagonite, which is formed at similar or even lower temperature than gelpalagonite.

A number of secondary minerals have now been discovered in the tephra (not considering those formed on the lava and in the lava craters). These minerals can be divided into two groups. First are minerals which apparently are a part of or are connected to the presence of sea-salts in the tephra at time of deposition: halite, aphtitalite and thenardite. Halite has presumeably been there from the time of deposition, but aphtitalite and thenardite may have been deposited when the water vapour emanations started to seep through the tephra. Second are minerals which are the product of palagonitization, they have from the beginning only been found where palagonitization has occurred, and the amount of these minerals is roughly proportional to the amount of palagonite at a given site. To this group belong opal (amorphous silica), chabasite (?), calcite, phillipsite (?) and probably smectites in the fibropalagonite, - listed in the order of first appearance.

\section{Surface exposures and volume of palagonitized tephra 1969-1976}

In Figs. 5-8 are shown surface exposures of palagonitized tephra from the period under inspection, exemplified by maps of 1969, 1970, 1972 and 1976. Included are areas showing incipient palagonitization of semiconsolidated tephra (cf. Fig. 4). In November 1969 (Fig. 5), less than 2 years after establishment of the thermal area some 1000$2000 \mathrm{~m}^{2}$ were palagonitized on surface, this is less than $1 / 2 \%$ of the total area of tephra, as measured on the map. In June 1976 (Fig. 8) some $109.000 \mathrm{~m}^{2}$ of palagonitized tephra was exposed or about $21 \%$ of the area covered by tephra. However, 


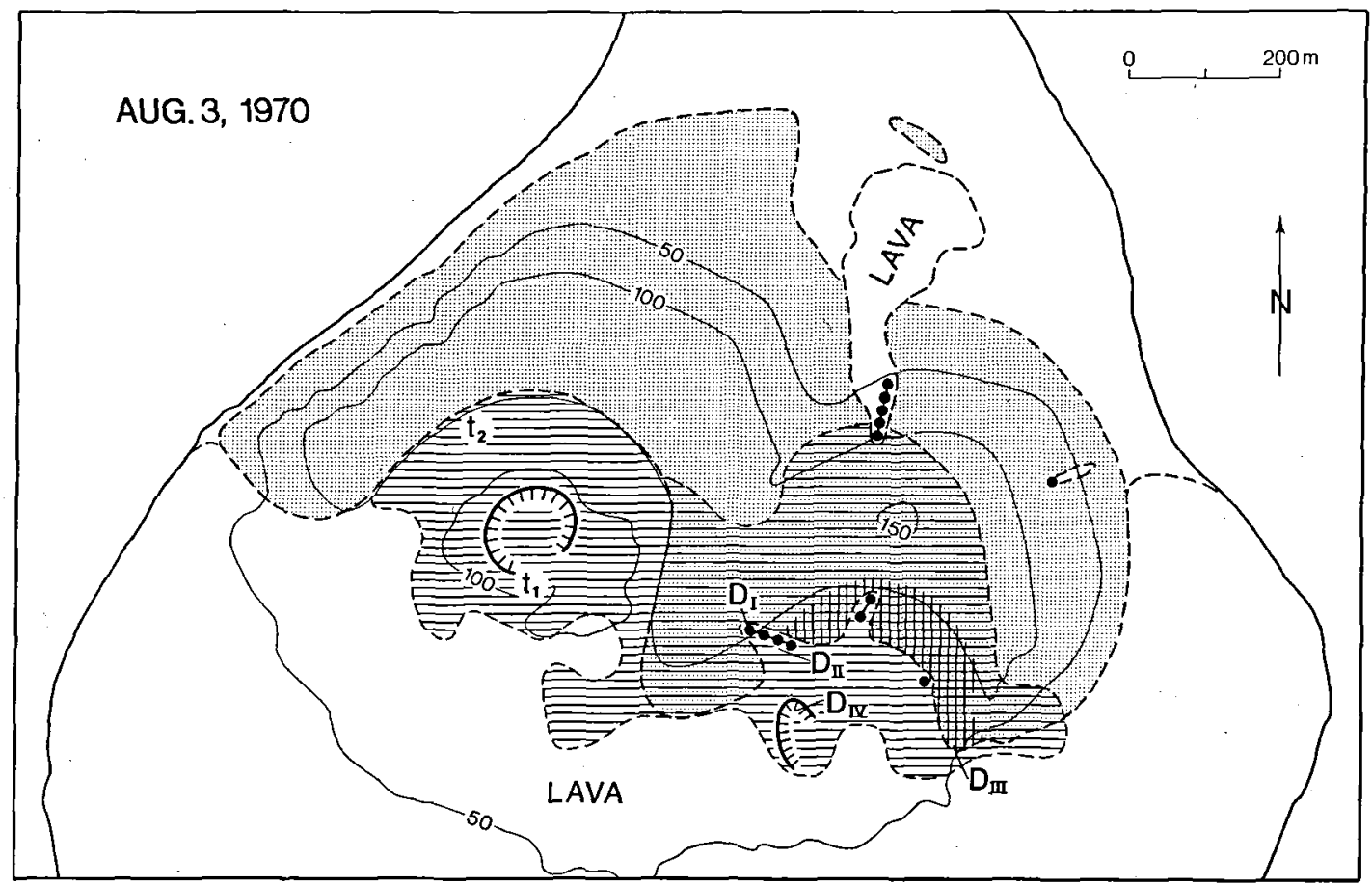

Fig. 6. Map of the northern part of Surtsey with the extent of the hydrothermal area and the surface exposures of palagonitized area as in August 1970. The extent of the thermal area in the lava field is mainly after Magnusson et al. 1972. Two localities for lava temperature measurements (Fig. 2) and localities for sampling of vapour condensates for deuterium analysis (Table 1) are shown. these numbers give no real idea about the volume of palagonitized and consolidated tephra. Because of the thermal gradient within the thermal area, the uppermost $30-50 \mathrm{~cm}$ have in place been palagonitized slowly, as they are often below some 50$60^{\circ} \mathrm{C}$ (Fig. 4). In the first years these areas will not be mapped as palagonitized, unless they are exposed by wind or water erosion. Eolian erosion is locally very intense, especially on top of the ridges, whereas tephra is redeposited in other areas, e.g. at the lower part of the flanks.

Using the maps of the thermal area (Fig. 5-8) and measurements on thermal gradients within it, and assuming that the shape of thermal anomaly is as shown in Fig. 3, it is simple to calculate the volume of palagonitized tephra. Around April 1969 , when all tephra at $100^{\circ} \mathrm{C}$ should have been palagonitized and consolidated (Fig. 4), some $38 \%$ of the volume of tephra above sealevel was converted to tuff. In August 1974, or roughly 61/2 years after the establishment of the thermal anomaly, tephra at temperature above $45^{\circ} \mathrm{C}$ was palanotized, or some $60 \%$ of the tephra pile. In Sep- tember 1976, the volume of tephra converted to tuff above about $45^{\circ} \mathrm{C}$ was $64 \%$. Here it should be noted, that as temperatures were generally falling after 1972-73 only a small part of the tephra pile is being palagonitized at temperatures below $\sim 45^{\circ} \mathrm{C}$. However, as the thermal area was gradually being enlarged, at least until 1976, more and more tephra is being converted to tuff.

As demonstrated before, sea water temperatures $\left(7-12^{\circ} \mathrm{C}\right)$ will probably prevail below sea level in the tephra pile. With reference to the results of Moore (1966), palagonitization, and therefore also consolidation, will proceed extremely slowly at these temperatures, it might take a couple of thousand years before this part of the tephra become consolidated.

After the tephra is consolidated, the conspicious bedding seemingly disappears. The bedding in the loose tephra (Jakobsson 1972, Figs. 1 and 2) becomes conspicuous mainly because of erosion, the wind picks out the fine-grained part of the layers. After consolidation the rocks is more evenly resistant to wind erosion and weathering, and bed- 


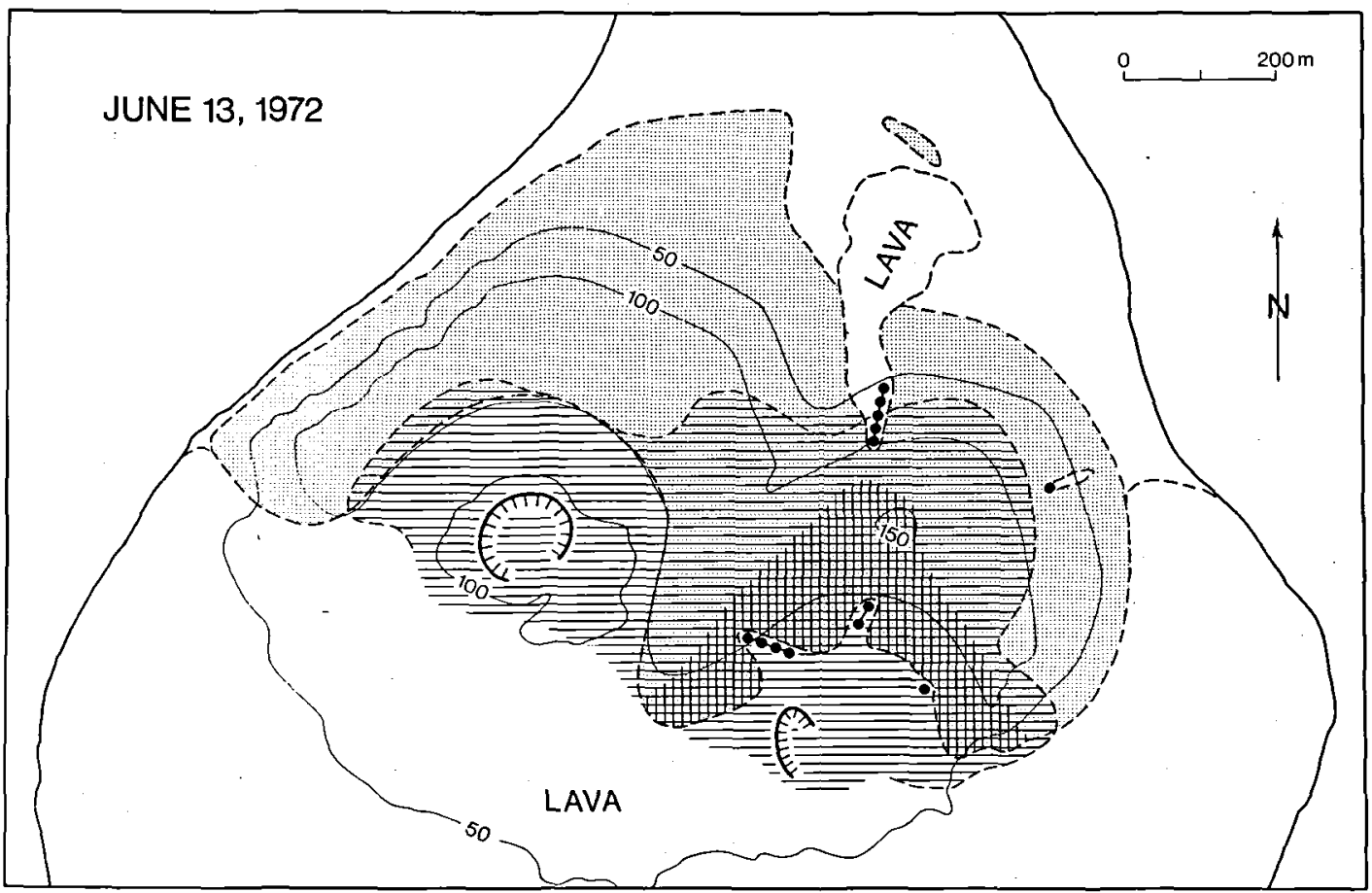

Fig. 7. Map of the northern part of Surtsey. Extent of the hydrothermal area and the surface exposures of palagonitized area as in June 1972.

ding is no longer conspicuous. Studies on the other islands within the Vestmannaeyjar archipelago (Jakobsson 1968) have shown, that the tuff is more resistant to marine abrasion than the lavas. The tuffs often form one compact mass, without any jointing or cleavage, the lavas, however, are easily eroded by wave action because of the jointing and the slaggy contacts.

\section{Discussion}

There appear to be only a few cases established in the literature where the exact conditions are known at which palagonitization has occured. These are palagonitization of the glass rind of submarine basaltic pillows adjacent to Hawaii, deduced to have occurred at $2-6^{\circ} \mathrm{C}$ and at water depths up to $5000 \mathrm{~m}$ (Moore 1966); palagonitization of the glassy skin of a historic lavaflow poured into Lake Motosu at Mount Fuji, Japan, deduced to have occurred at $\leq 17^{\circ} \mathrm{C}$ and at a water depth down to $15 \mathrm{~m}$ (Moore 1966); palagonitization of the glassy crust of the 1919 lava along steaming cracks on the floor of Kilauea caldera, observed to happen at a temperature range of $76-91^{\circ} \mathrm{C}$ and a $\mathrm{pH}$ of approximately 6 (Hay et al. 1969, abstract). To these can now be added the Surtsey case, where palagonitization of the basaltic tephra so far has been observed to occur at $\sim 45-100^{\circ} \mathrm{C}$, about $1 \mathrm{~atm}$. and $\mathrm{pH}$ of $7.7-8.2$, the palagonitizing agent being vapourized sea water and meteoric water. In addition, Furnes (1975) has determited experimentally the rate of palagonitization of three basaltic glasses as a function of temperature $\left(20-90^{\circ} \mathrm{C}\right)$ and time (3.5 - 14 months) in both fresh and saline water. The rate of palagonitization was found to be about three times faster at $90^{\circ}$ than $20^{\circ} \mathrm{C}$.

Workers within the last 50 years or so studying palagonitization, have advanced strongly differing suggestions as to the time and temperature of the process. These can be put into four categories: Those who have argued that the palagonite was formed at very high temperatures at or near time of eruption, especially in water medium i.e. Fuller (1932) Wentworth (1938), Nayudu (1964) and Bonatti (1965); Matthews (1962) suggested that gel- 


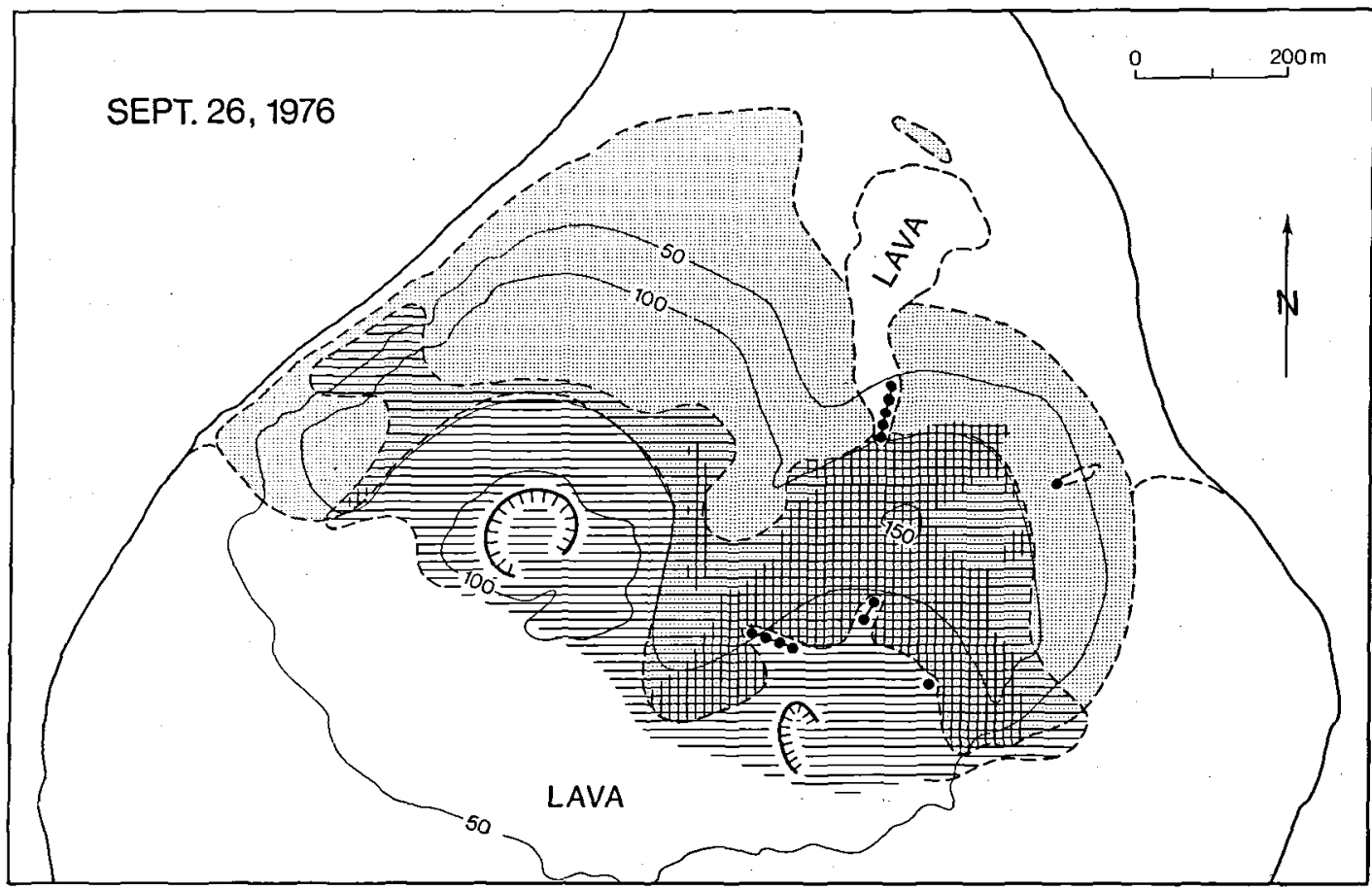

Fig. 8. Map of the northern part of Surtsey. Extent of the hydrothermal area and the surface exposures of palagonitized area as in September 1976.

palagonite was formed at high temperature during the initial coling, whereas fibropalagonite formed at very low temperatures. Those who have argued that palagonite is a post-eruptional alteration but occurring mostly at high temperatures (approx. 200-400 ${ }^{\circ} \mathrm{C}$ ), i.e. Correns (1930) and Hoppe (1940). Finally there are those who have argued that palagonitization in the respective cases occurs posteruptionally, 1) at ambient temperatures on sea- or lake bottom or subaerially, i.e. Peacock (1926, for gelpalagonite), Noe-Nygaard (1940), Jónsson (1961), Matthews (1962, for fibropalagonite), Moore (1966), Honnorez (1972) and Muehlenbachs \& Clayton (1972); or 2) at both ambient weathering conditions and by mild hydrothermal activity near or at surface, i.e. Peacock (1926), Hay \& Ijima (1968), Sigvaldason (1968), McBirney \& Williams (1969), Hay et al. (1969), Heiken (1972), Jakobsson (1972) and Furnes (1975).

It has never been convincingly shown that palagonite forms at high temperatures, as suggested by the two first groups mentioned above. The initial tephra formed in historic basaltic eruption has always been shown to consist of fresh glass, such as in the case of the Vatnajökull and Grimsvötn subglacial eruptions of 1903, 1922 and 1934 in Iceland (Barth 1937, Noe-Nygaard 1951), in the case of the Puu Hou littoral cones formed in 1868 in a lava flow from Mouna Loa (Fisher 1968), and in the Surtsey tephra which was formed in 19631964 (Jakobsson 1972). Basaltic glass which has been altered at temperatures above some $150^{\circ} \mathrm{C}$ does probably not turn into anything which can be classified as palagonite. These are metamorphic conditions and the product will probably mainly be clay minerals and zeolites without any appreciable amount of glass. It can therefore be concluded, that palagonitization is a posteruptional process, occurring at relatively low temperatures, mostly below $100^{\circ} \mathrm{C}$, and at low pressures.

On basis of the present author's experience on Surtsey and the subglacial pleistocene hyaloclastistes of Iceland and from survey of the literature, it is probable that the conditions at which palagonitization of basaltic glass occurs on earth are mainly of four different categories.

First, there is palagonitization in sea water, which will occur mainly at $0-20^{\circ} \mathrm{C}$ and mostly at 
less than $0.6 \mathrm{~kb}$ e.g. the study of Moore (1966) on pillow lavas adjacent to Hawaii. This must be very common, because of the extensive areas on the sea-bottom covered with glassy basalts.

Second, palagonitization in fresh water. Probably mainly at $0^{\circ}-20^{\circ} \mathrm{C}$ and low pressures. Palagonitization at these conditions is probably comparatively rare. The only investigated case appears to be the study of Moore (1966) on a lava flow which flowed into a lake NE of Mount Fuji.

Third, palagonitization in mild, usually shortlived, hydrothermal systems near or at surface. In this case, the temperatures are mostly at 50$100^{\circ} \mathrm{C}$, rarely above $100^{\circ} \mathrm{C}$, and pressure is seldom more than few atmospheres. This category may be fairly common with Surtsey as an example.

Fourth, palagonitization in humid, to waterlogged rocks at weathering conditions on land, at or close to the surface and mostly at $0^{\circ}-25^{\circ} \mathrm{C}$ and 1 atm or slightly above. As mentioned before this may be very common, with the study of Hay \& Ijima (1968a, 1968b) on the tuff deposits of the Koko Crater group, Oahu, Hawaii, as an example. In some cases there may not be a clear distinction between categories 2 and 4 .

Basaltic glasses, formed at surface and in rare cases at some depth, may finally be buried under other rocks, and may gradually be exposed to rising temperatures and pressures until they reach what conventionally is termed metamorphic conditions. The low-temperature limit of metamorphism is set by Miyashiro at around $150^{\circ} \mathrm{C}$ (Miyashiro 1973).

Most geologists would probably classify palagonitization which proceeds at atmospheric or seawater temperatures (categories 1,2 and 4) as a weathering process, and palagonitization at 40$150^{\circ} \mathrm{C}$ (category 3 ) as a mild hydrothermal alteration.

As far as present knowledge goes, there are only a few petrographic and chemical criteria which are of use to distinguish between some of the four categories listed above. The occurrence of dark red to red-brown gelpalagonite in Surtsey may be indicative of palagonitization at moderate temperatures (Jakobsson 1971). Similarily, observations which indicate that steam has moved through the rock, such as predominant palagonitization on one side (usually underside) of glass shards are indicative of the third category. It seems also well established that on the assumption of constant volume alteration there are certain chemical differences between palagonite formed in sea water and that formed under weathering conditions and in mild hydrothermal activity on land. Palagonite from the sea bottom characteristically shows enrichment in $\mathrm{K}_{2} \mathrm{O}$ and loss in $\mathrm{TiO}_{2}$, in contrast to palagonite from land which exhibits a marked decrease in $\mathrm{K}_{2} \mathrm{O}$ and an enriched or constant $\mathrm{TiO}_{2}$ value (Peacock 1926, Correns 1930, Honnorez 1972 and Muehlenbachs \& Clayton 1972).

Acknowledgements. The Surtsey Research Society is thanked for logistic support. Bragi Arnason, The University of Iceland, advised how to collect water condensate samples and kindly made the deuterium analyses. Bjorn Johansson did some of the temperature measurements. X-ray analyses (Guinier method) on palagonite and secondary minerals were carried out by $\mathrm{E}$. Leonardsen, Mineralogical Institute, Univ. of Copenhagen. C.K. Brooks, Petrological Institute, ibid., kindly corrected the English of the manuscript. Reviews by J. Honnorez and J.G. Moore are greatly acknowledged. R. Larsen is thanked for preparing the final draft of the figures.

\section{Dansk sammendrag}

Surtsey-tefraen blev dannet mellem den 14, november 1963 og den 4. april 1964 under Surtsey-udbruddets undersøiske fase. Siden da, er tefraen blevet undersøgt àrligt for at følge forløbet af den forventede konsolidering og palagonitisering. I 1969 konstaterede de første tegn pá palagonitisering af det basaltiske glas - tydeligvis i tilknytning til en i 1968 opstået hydrotermal anomali i tefralagsøjlen. Varmetilførselen antages at være sket gennem konvektion af fordampet havvand og meteorisk vand. Varmekilden har været tilførselsgange og overfladenære intrusioner. Palagonitdannelsen fra 1969-1976 kan vises at være foregáet ved ca. $100^{\circ} \mathrm{C}$ og $1 \mathrm{~atm}$ undtagen $i$ de overste $0,5-2 \mathrm{~m}$, hvor processen er forløbet ved temperaturer helt ned til $40^{\circ} \mathrm{C}$. Hvor fremskreden graden af konsolidering og palagonitisering er, bedømmes til at være en funktion af temperatur og tid. Muligvis blev det meste af tefralagene inden for den hydrotermale anomali palagonitiseret pà mindre end $1-1 \frac{1}{2} \mathrm{ar}$, og i 1976 skønnes ca. $64 \%$ af den totale tefralagsøjle at være blevet palagonjtiseret. Afsluttende diskuteres de generalle betingelser for palagonitdannelse.

\section{References}

Arnason, B 1977: Hydrothermal systems in Iceland traced by deuterium. Geothermics 5: 125-151.

Arnason, B. \& Sigurgeirsson, Th. 1968: Deuterium content of water vapour and hydrogen in volcanic gas at Surtsey, Iceland. Geochim. Cosmochim. Acta 32: 807-813.

Barth, T.F.W. 1937: Volcanic ash from Vatnajokull. Norsk Geol. Tidsskr. 17: 31-38.

Bonatti, E. 1965: Palagonite, hyaloclastites and alteration of volcanic glass in the Ocean. Bull. Volc. $28: 257-268$.

Correns, G.W. 1930: Uber einen Basalt vom des atlantischen Ozeans und seine Zersetzungsrinde. Chemie der Erde 5: 7686.

Dietrich, G., Kalle, K., Krauss, W. \& Siedler, G. 1975: Allgemeine Meereskunde. Borntraeger, Berlin. 593 p. 
Fisher, R.V. 1961: Proposed classification of volcaniclastic sediments and rocks. Bull. Geol. Soc. Amer. 72: 1409-1414.

Fisher, R.V. 1968: Puu Hou littoral cones. Geol. Rundsch. 57: 837-864.

Friedman, J.D. \& Williams, R.S. 1970: Changing patterns of thermal emission from Surtsey, Iceland, between 1966 and 1969. U.S. Geol. Survey Prof. Paper 700-D, 116-124.

Friedman, G., Preble, D.M. \& Jakobsson, S.P. 1976: Geothermal flux through palagonitized tephra, Surtsey, Iceland. The Surtsey temperature-data-relay experiment via Landsat - 1. Journ. Research U.S. Geol. Survey, 4: 645-659.

Fuller, R.E. 1932: Concerning basaltic glass. Amer. Mineral. 17: 104-107.

Furnes, H. 1975: Experimental palagonitization of basaltic glasses of varied composition. Contr. Mineral. Petrol. 50: 105-113.

Hay, R.L. \& Ijima, A. 1968 a: Petrology of palagonite tuffs of Koko crater, Oahu, Hawaii. Contr. Mineral. Petrol. 17: 141 $-154$.

Hay, R.L. \& Ijima, A. 1968 b: Nature and origin of palagonite tuffs of the Honolulu Group on Oahu, Hawaii. Geol. Soc. Amer. Memoir 116: 331-376.

Hay, R.L., Burns, L.K. and Drake, R. 1969: Palagonitic alteration along steaming cracks in Kilauea caldera, Hawaii Geol. Soc. Amer. Abstracts for 1969.

Heiken, G.H. 1972: Tuff rings of the Fort Rock-Christmas Lake valley basin, South-Central Oregon. Ph. D. thesis (unpubl.), Univ. of California.

Hoppe, H.-G. 1940: Untersuchungen an Palagonittuffen und uber ihre Bildungsbedingungen. Chem. der Erde 13: 484514.

Honnorez, J. 1972: La Palagonitization: l'alteration sousmarine du verre volcanique basique de Palagonia (Sicile). Vulkaninstitut I. Friedlaender, Zürich, No. 9, 132 pp.

Jakobsson, S.P. 1968: The geology and petrography of the Westman Islands. A preliminary report. Surtsey Res. Progr. Rep. IV, 113-129.

Jakobsson, S.P. 1971: Palagonitiseringen af tefraen pả Surtsey. Natturufraedistofnun Islands (mineographed), $61 \mathrm{p}$.

Jakobsson, S.P. 1972: On the consolidation and palagonitization of the tephra of the Surtsey volcanic island, Iceland. Surtsey Res. Progr. Rep. VI: 121-128.

Jóhannesson, Ae. (in press): The thermal anomaly in Surtsey revisited. Surtsey Res. Progr. Rep. VIII.

Jones, J.G. 1970: Interglacial volcanoes of the Laugarvatn region, southwest Iceland, II. Journ. Geology 78: 127 140.

Jonsson, G. 1961: Some observations on the occurrence of sideromelane and palagonite. Bull. Geol. Inst. Univ. of Uppsala 40: 81-86.

Kjartansson, G. 1966: Stapakenningin og Surtsey. (A comparison of tablemountains in Iceland and the volcanic island Surtsey off the south coast of Iceland). Natturufraedingurinn 36: 1-34.

Lorenz, V. 1974: Studies of the Surtsey tephra deposits. Surtsey Res. Prog. Rep. VII: 72-78.

Magnusson, S., Sveinbjornsson, B. \& Fridriksson, S. 1972: Substrate temperature measurements and location of thermal areas on Surtsey, summer 1970. Surtsey Res. Progr. Rep. 6: 82-85.

Matthews, D.H. 1962: Altered lavas from the floor of the Eastern North Atlantic. Nature 194: 368-369.

McBirney, A.R. 1963: Factors governing the nature of submarine volcanism. Bull. Volc. 26: 455-469.

McBirney, A.R. \& Williams H. 1969: Geology and petrology of the Galapagos Islands. Geol. Soc. Amer., Memoir 118, 197 pp.

Miyashiro, A. 1973: Metamorphism and metamorphic belts. London.

Moore, J.G. 1966: Rate of Palagonitization of submarine basalt adjacent to Hawaii, U.S. Geol. Prof. Paper 550-D, 163-171.
Muehlenbachs, K. \& Clayton, R.N. 1972: Oxygen isotope studies of fresh and weathered submarine basalts. Canad. Journ. of Earth Sciences 9: 172-184.

Nayudu, Y.R. 1964: Palagonite tuffs (hyaloclastites) and the products of post-eruptive processes. Bull. Volc. 27: 1-20.

Noe-Nygaard, A. 1940: Sub-glacial volcanic activity in ancient and recent times. Folia Geographica Danica 1,2.

Noe-Nygaard, A. 1951: Materials from the eruption in Grimsvötn, Vatnajobull, in 1934. Folia Geographica Danica 1,4

Norrman, J.O. 1970: Trends in postvolcanic development of Surtsey Island. Surtsey Res. Progr. Rep. V: 95-112.

Peacock, M. 1926: The petrology of Iceland (Tyrrell and Peacock), Part I, the basic tuffs. Trans. Roy. Soc. Edinburgh 55: 51-76.

Saemundsson, K. 1967: Vulkanismus und Tektonik des HengillGebietes in südwest-Island. Acta Natur. Islandica. Vol. II, no. $7,105 \mathrm{pp}$.

Sartorius von Walterhausen, W. 1845: Ueber die submarinen Ausbrüche in der Tertiär-Formation des Val di Noto im Vergleich mit verwandten Erscheinungen am Aetna. Gött. Studien I: 371-431.

Sigtryggsson, H. 1970: Preliminary report of the results of meteorological observations on Surtsey 1968. Surtsey Res. Progr. Rep. V: 119-120.

Sigurgeirsson, Th. 1966: Geophysical measurements in Surtsey carried out during the year of 1965. Surtsey Res. Progr.Rep. II: $\mathbf{1 8 1}-185$.

Sigurgeirsson, Th. 1974: Final report on geomagnetic measurements. Surtsey Res. Progr. Rep. IV: 91-94.

Sigvaldason, G.E. 1968: Structure and products of subaquatic volcanoes in Iceland. Contr. Mineral. Petrol. 18: 1-16.

Sigvaldason, G.E. \& Fridriksson, S. 1968: Water soluble leachate of volcanic ash from Surtsey. Surtsey Res. Progr. Rep. IV: 163-164.

Thorarinsson, S. 1966: Sitt af hverju um Surtseyjargosid (Some facts about the Surtsey Eruption). Natturufraedingurinn 35: 153-181.

Thorarinsson, S. 1968: Sidustu thaettir Eyjaelda (The last phases of the Surtsey eruption). Natturufraedringurinn 38: 113135.

Thorarinsson, S., Einarsson, Th., Sigvaldason, G.E. \& Elisson, G. 1964: The submarine eruption off the Westman Islands 1963-64. Bull. Volc. 27: 1-11.

Vedrattan (Monthly weather bulletin) 1970. The Icelandic Weather Bureau, Reykjavik.

Walker, G.P.L. \& Croasdale, R. 1972: Characteristics of some basaltic pyroclastics. Bull. Volc. 35: 303-319.

Wentworth, C.K. 1938: Ash formation in the Island Hawaii. Hawaiian Volcan. Observ. Spec. Rep. 3. 